\title{
Acute Toxoplasmosis among Canadian Deer Hunters Associated with Consumption of Undercooked Deer Meat Hunted in the United States
}

Colette Gaulin, Danielle Ramsay, Karine Thivierge, Joanne Tataryn, Ariane Courville, Catherine Martin, Patricia Cunningham, Joane Désilets, Diane Morin, Réjean Dion

\begin{abstract}
$\underset{\text { MDUCAISCAN }}{\text { MediVITY }}$
In support of improving patient care, this activity has been planned and implemented by Medscape, LLC and Emerging Infectious Diseases. Medscape, LLC is jointly accredited by the Accreditation Council for Continuing Medical Education (ACCME), the Accreditation Council for Pharmacy Education (ACPE), and the American Nurses Credentialing Center (ANCC), to provide continuing education for the healthcare team.

Medscape, LLC designates this Journal-based CME activity for a maximum of 1.00 AMA PRA Category 1 Credit(s) $^{\mathrm{TM}}$. Physicians should claim only the credit commensurate with the extent of their participation in the activity.

Successful completion of this CME activity, which includes participation in the evaluation component, enables the participant to earn up to $1.0 \mathrm{MOC}$ points in the American Board of Internal Medicine's (ABIM) Maintenance of Certification (MOC) program. Participants will earn MOC points equivalent to the amount of CME credits claimed for the activity. It is the CME activity provider's responsibility to submit participant completion information to ACCME for the purpose of granting ABIM MOC credit.

All other clinicians completing this activity will be issued a certificate of participation. To participate in this journal CME activity: (1) review the learning objectives and author disclosures; (2) study the education content; (3) take the post-test with a 75\% minimum passing score and complete the evaluation at http://www.medscape.org/journal/eid; and (4) view/print certificate. For CME questions, see page 398.
\end{abstract}

Release date: January 17, 2020; Expiration date: January 17, 2021

Learning Objectives

Upon completion of this activity, participants will be able to:

- Analyze how humans may become infected with toxoplasma

- Assess the symptoms and consequences of toxoplasma infection

- Assess the clinical presentation of toxoplasmosis in a cohort of deer hunters

- Evaluate the laboratory evaluation of this cohort of deer hunters

\section{CME Editor}

Thomas J. Gryczan, MS, Technical Writer/Editor, Emerging Infectious Diseases. Disclosure: Thomas J. Gryczan, MS, has disclosed no relevant financial relationships.

\section{CME Author}

Charles P. Vega, MD, Health Sciences Clinical Professor of Family Medicine, University of California, Irvine School of Medicine, Irvine, California. Disclosure: Charles P. Vega, MD, has disclosed the following relevant financial relationships: served as an advisor or consultant for Genentech, Inc.; GlaxoSmithKline; Johnson \& Johnson Pharmaceutical Research \& Development, L.L.C.; served as a speaker or a member of a speakers bureau for Shire

\section{Authors}

Disclosures: Colette Gaulin, MD, MSc; Danielle Ramsay, MSc; Karine Thivierge, PhD; Joanne Tataryn, DVM; Ariane Courville, MD, MSc; Catherine Martin, BSc; Patricia Cunningham, BSc(N); Joane Désilets, MD, MSc; Diane Morin, MD; and Réjean Dion, MD, have disclosed no relevant financial relationships.

Author affiliations: Ministère de la Santé et des Services Sociaux, Quebec City, Quebec, Canada (C. Gaulin); Ministère de l'Agriculture, des Pêcheries, et de l'Alimentation du Quebec, Quebec City (D. Ramsay); Institut National de Santé Publique du Québec, Sainte-Anne-de-Bellevue, Quebec, Canada (K. Thivierge, R. Dion); Canadian Public Health Agency, Ottawa, Ontario, Canada (J. Tataryn); Direction de Santé Publique Gaspésie-
Îles-de-la-Madeleine, Gaspé, Quebec, Canada (A. Courville); Direction de la Santé Publique du Bas St-Laurent, Quebec City (C. Martin); Direction de Santé Publique Lanaudière, Joliette, Quebec, Canada (P. Cunningham, J. Désilets); Centre Intégré de Santé et de Services Sociaux de Chaudière-Appalaches, Sainte-Marie de Beauce, Quebec, Canada (D. Morin) DOI: https://doi.org/10.3201/eid2602.191218 
We conducted a recent investigation in Quebec, Canada, concerning Canadian deer hunters who went to the United States to hunt deer and returned with symptoms of fever, severe headache, myalgia, and articular pain of undetermined etiology. Further investigation identified that a group of 10 hunters from Quebec attended a hunting retreat in Illinois (USA) during November 22-December 4, 2018. Six of the 10 hunters had similar symptoms and illness onset dates. Serologic tests indicated a recent toxoplasmosis infection for all symptomatic hunters, and the risk factor identified was consumption of undercooked deer meat. Among asymptomatic hunters, 2 were already immune to toxoplasmosis, 1 was not immune, and the immune status of 1 remains unknown. Outbreaks of acute toxoplasmosis infection are rare in North America, but physicians should be aware that such outbreaks could become more common.

$T$ oxoplasma gondii is one of the most common zoonotic parasites and can cause serious illness in humans and other animals worldwide (1-3). It can infect virtually all warm-blooded animals, including birds, livestock, marine mammals, and humans (2). Felids are the definitive hosts of $T$. gondii, meaning they are the only animals in which replication can result in the production of oocysts (eggs), which are then shed in the feces $(2,3)$. Felids are essential to the epidemiology of this parasite (2).

Human T. gondii infection is caused by ingestion of tissue cysts in undercooked meat; ingestion of soil, water, or food contaminated with oocysts; or, less frequently, directly from feline feces (3-8). Frequency of human infection might vary substantially by region because of ecologic, social, and cultural factors (3).

T. gondii infection acquired after birth can be asymptomatic in humans. Symptoms appear mostly in immunocompromised persons. When symptoms develop, they are nonspecific and include malaise, fever, headache, sore throat, arthralgia, and myalgia.

Lymphadenopathy, frequently cervical, is the most common sign (3). Persons remain infected for life (3). Reactivation of the disease is possible sometimes years later. However, outbreaks of acute toxoplasmosis seem to be rare.

Cervids can be infected by T. gondii (2,7,9-12). Cases of clinical toxoplasmosis have been documented in humans who had consumed undercooked venison (13). Toxoplasmosis infection was documented in 1 Alabama and 2 South Carolina deer hunters during 1980 (14). A recent outbreak was reported in the United States during 2017 (15). However, it is quite rare to observe a cluster of cases related to undercooked deer meat, particularly related to consumption of venison. In addition, cysts and oocysts of
T. gondii are destroyed by freezing. We report an acute toxoplasmosis outbreak in Quebec, Canada, associated with consumption of venison. We conducted an investigation to determine the outbreak magnitude, describe illness-related factors, and coordinate Toxoplasma spp. diagnostic testing.

\section{Background}

On December 20, 2018, public health authorities in Quebec were alerted regarding a patient with fever, severe headache, myalgia, and articular pain of undetermined etiology. The first symptom onset occurred on December 8. The patient required hospitalization; medical history showed no chronic or immunologic disease.

Further investigation identified that this patient and 9 hunter companions from Quebec attended a hunting retreat in Illinois (USA) during November 22-December 4, ending the week before illness began. Six of the 10 hunters had similar symptoms and illness onset dates. Case-patients reported consuming undercooked venison during the retreat. Hunters were tested for $\mathrm{Q}$ fever, hepatitis E, leptospirosis, brucellosis, Lyme disease, and toxoplasmosis. Serologic tests indicated recent toxoplasmosis infections.

\section{Material and Methods}

\section{Case Definition}

A confirmed case was defined by serologic test results (IgM positive for toxoplasmosis and a low-avidity test result). These results were consistent with a recently acquired Toxoplasma spp. infection in a person who had clinical symptoms compatible with toxoplasmosis after attending the deer hunting retreat during November 22-December 4, 2018.

\section{Epidemiologic Investigation}

On December 20, 2018, the Direction de la Vigie Sanitaire at the Ministère de la Santé et des Services Sociaux (Ministry of Health in Quebec) initiated an investigation. This investigation was conducted in collaboration with the Ministère de l'Agriculture, des Pêcheries et de l'Alimentation du Quebec (MAPAQ: Ministry of Agriculture, Fisheries, and Food of Quebec), public health units, and the Laboratoire de Santé Publique du Quebec (LSPQ: Public Health Laboratory in Quebec).

All 10 hunting companions who attended the retreat in Illinois were interviewed. The following information was collected from each attendee, symptomatic or asymptomatic: demographic information; description of activities at the outfitter, including 
deer hunting and evisceration; food consumed on site, including deer meat and how it was eaten (raw, undercooked, or well done); consumption of water; and possible exposure to ticks or other animals. For persons who had symptoms, we obtained information on onset dates and symptoms. Attendees were interviewed mostly by public health nurses or medical microbiologists and infectious disease physicians.

\section{Food Inspection Services}

Deer meat harvested during the trip was available, and we collected specimens from hunter households. Meat samples were collected by the food inspection services at the MAPAQ and analyzed by the Molecular Diagnosis Laboratory at the Veterinary School at the University of Montreal (Montreal, Quebec, Canada) by using standardized and adapted methods (16).

\section{Serologic Tests}

We tested symptomatic and asymptomatic hunters by using serologic analysis for toxoplasmosis, brucellosis, leptospirosis, Q fever, hepatitis E, West Nile virus (WNV), and Lyme disease. We detected T. gondii IgG and IgM by using VIDAS TOXO IgM and IgG II assays (bioMérieux, https://www.biomerieux.com). When T. gondii IgG was detected, we analyzed serum samples by using the Vidas Toxo IgG Avidity Assay (bioMérieux). Cutoff values used to interpret the results were those recommended by the manufacturers. All Toxoplasma spp. analyses were conducted at the LSPQ.

Other analyses were ordered. These analyses were detection of WNV IgM by ELISA using the WNV IgM Capture DxSelect (Focus Diagnostics, https:/ /www.focusdx.com) at the LSPQ; detection of Brucella spp. IgM and IgG by using the standard tube Brucella agglutination test (in-house test at the LSPQ); detection of hepatitis E virus IgG and IgM by using a diagnostic assay (Wantai Biologic Pharmacy Enterprise, http:/ /www.ystwt.cn); detection of Leptospira spp. IgM by using the Panbio Leptospira IgM ELISA (Abbott, https://www.abbott.com); detection of Coxiella burnetii IgG by using an immunofluorescence assay at the Centre Hospitalier Universitaire de Sherbrooke (Sherbrooke, Quebec, Canada); detection of Borrelia burgdorferi IgM and IgG by using the 2-tiered algorithm that included a screening ELISA conducted at Centre Hospitalier Universitaire de Sherbrooke (Zeus ELISA Borrelia VlsE1/pepC10 IgG/ IgM test system; Alere, https://www.alere.com); an IgG Western blot assay (Anti-Borrelia burgdorferi U.S. EUROLINE-WB IgG; Euroimmun, https://www. euroimmun.com); and an IgM Line Blot Assay (AntiBorrelia EUROLINE-RN-AT-adv IgM; Euroimmun) performed at the National Microbiology Laboratory in Winnipeg, Ontario, Canada.

\section{Results}

\section{Epidemiologic Investigation}

All 10 persons interviewed were men (age range 2862 years). None of them had preexisting medical conditions. Clinical symptoms developed in 6 patients, including headache, fever, sweats, myalgia, and joint pain, during December 8-11, 2018; the earliest symptoms began a few days after the men returned home from Illinois. One case-patient was hospitalized because of severe headache, fever, and myalgia. Three other case-patients consulted a physician but were not hospitalized, and 2 other case-patients had similar symptoms but did not consult any physician.

We compiled results of Toxoplasma spp. testing and deer meat consumption for each hunter (Table). Toxoplasma spp. IgM was detected in 6 serum samples collected during the acute disease phase for the 6 symptomatic hunters. For 1 symptomatic hunter, Toxoplasma spp. IgM was detected when a second blood specimen was collected 3 weeks later. No IgG was detected in these serum samples, which suggested a recent infection in these hunters. We detected IgG with a low avidity index in the 6 serum samples collected from 6 case-patients during the convalescent phase, which enabled confirmation of a recent infection for all of these case-patients. For the 4 asymptomatic hunters, we analyzed 3 serum samples and detected IgG with a high avidity index in 2 samples, which suggested that both hunters were already immune to toxoplasmosis; 1 asymptomatic hunter was considered to be nonimmune. Even if this hunter consumed fresh deer meat that was undercooked, he did not show development of any disease and did not have any positive test results. One asymptomatic hunter did not participate in testing. When performed, serologic assays for hepatitis E, Q fever, leptospirosis, brucellosis, and Lyme disease all showed negative results.

We explored many possible risk factors to determine the most likely source of infection during the stay of the hunters, including water, food, and animal exposures. The hunters stayed at the camp for 12 days and during that time harvested and dressed 2-3 deer each. On November 30, the hunters prepared and consumed fresh deer steak that was cooked rare. Five of the 6 symptomatic hunters consumed rare steak, and 1 consumed steak cooked medium. Among the 
Table. Characteristics of 10 hunters who had suspected toxoplasmosis, Quebec, Canada, 2018*

\begin{tabular}{|c|c|c|c|c|c|c|c|}
\hline Hunter & Illness & Signs/symptoms & $\begin{array}{l}\text { Consumption } \\
\text { of deer meat }\end{array}$ & Collection date & Test & Result & Conclusion \\
\hline 1 & Yes & $\begin{array}{l}\text { Fever, sweats, } \\
\text { cephalalgiamuscular, } \\
\text { joint pain, fatigue }\end{array}$ & Rare steak & 2019 Jan11 & $\begin{array}{c}\lg M \\
\lg G \text { II } \\
\text { IgG avidity } \\
\text { IgM } \\
\text { IgG II } \\
\text { IgG avidity }\end{array}$ & $\begin{array}{l}\text { Negative } \\
\text { Negative } \\
\text { NA } \\
\text { Positive } \\
\text { Positive } \\
\text { Low avidity }\end{array}$ & Acute toxoplamosis \\
\hline 2 & Yes & $\begin{array}{l}\text { Fever, sweats, } \\
\text { cephalalgia, muscular, } \\
\text { joint pain, fatigue }\end{array}$ & Rare steak & 2018 Dec 21 & $\begin{array}{c}\text { IgM } \\
\text { IgG II } \\
\text { IgG avidity }\end{array}$ & $\begin{array}{l}\text { Positive } \\
\text { Negative } \\
\text { NA }\end{array}$ & Acute toxoplamosis \\
\hline 3 & Yes & $\begin{array}{l}\text { Fever, sweats, } \\
\text { cephalalgia, muscular, } \\
\text { joint pain, fatigue }\end{array}$ & Rare steak & $\begin{array}{l}2018 \text { Dec } 20 \\
2019 \text { Jan } 14\end{array}$ & $\begin{array}{c}\lg M \\
\text { IgG II } \\
\text { IgG avidity } \\
\text { IgM } \\
\text { IgG II } \\
\text { IgG avidity }\end{array}$ & $\begin{array}{c}\text { Positive } \\
\text { Equivocal } \\
\text { NA } \\
\text { Positive } \\
\text { Positive } \\
\text { Low avidity }\end{array}$ & $\begin{array}{l}\text { Acute toxoplamosis } \\
\text { Acute toxoplamosis }\end{array}$ \\
\hline 4 & Yes & $\begin{array}{l}\text { Fever, cephalagie, } \\
\text { photophobic }\end{array}$ & Rare steak & $\begin{array}{l}2018 \text { Dec } 20 \\
2019 \text { Jan } 14\end{array}$ & $\begin{array}{c}\lg M \\
\lg G \text { II } \\
\text { IgG avidity } \\
\text { IgM } \\
\text { IgG II } \\
\text { IgG avidity }\end{array}$ & $\begin{array}{l}\text { Positive } \\
\text { Negative } \\
\text { NA } \\
\text { Positive } \\
\text { Positive } \\
\text { Low avidity }\end{array}$ & $\begin{array}{l}\text { Acute toxoplamosis } \\
\text { Acute toxoplamosis }\end{array}$ \\
\hline 5 & Yes & $\begin{array}{c}\text { Fever, sweats, } \\
\text { cephalalgia, muscular, } \\
\text { joint pain, fatigue }\end{array}$ & Medium steak & $\begin{array}{l}2018 \text { Dec } 19 \\
2019 \text { Jan } 4\end{array}$ & $\begin{array}{c}\lg M \\
\text { IgG II } \\
\text { IgG avidity } \\
\text { IgM } \\
\text { IgG II } \\
\text { IgG avidity }\end{array}$ & $\begin{array}{l}\text { Positive } \\
\text { Negative } \\
\text { NA } \\
\text { Positive } \\
\text { Positive } \\
\text { Low avidity }\end{array}$ & $\begin{array}{l}\text { Acute toxoplamosis } \\
\text { Acute toxoplamosis }\end{array}$ \\
\hline 6 & Yes & $\begin{array}{c}\text { Fever, sweats, } \\
\text { cephalalgia, muscular, } \\
\text { joint pain, fatigue }\end{array}$ & Rare steak & $\begin{array}{l}2018 \text { Dec } 16 \\
2019 \text { Jan } 4\end{array}$ & $\begin{array}{c}\lg M \\
\text { IgG II } \\
\lg \text { avidity } \\
\text { IgM } \\
\text { IgG II } \\
\text { IgG avidity }\end{array}$ & $\begin{array}{l}\text { Positive } \\
\text { Negative } \\
\text { NA } \\
\text { Positive } \\
\text { Positive } \\
\text { Low avidity }\end{array}$ & $\begin{array}{l}\text { Acute toxoplamosis } \\
\text { Acute toxoplamosis }\end{array}$ \\
\hline 7 & No & Asymptomatic & $\begin{array}{l}\text { Rare steak } \\
\text { and heart }\end{array}$ & 2019 Feb 7 & $\begin{array}{l}\lg M \\
\lg G||\end{array}$ & $\begin{array}{l}\text { Negative } \\
\text { Negative }\end{array}$ & $\begin{array}{c}\text { Asymptomatic and } \\
\text { nonimmune }\end{array}$ \\
\hline 8 & No & Asymptomatic & $\begin{array}{l}\text { Well-done } \\
\text { steak }\end{array}$ & 2019 Jan 15 & $\begin{array}{c}\lg M \\
\lg G \text { II } \\
\text { IgG avidity }\end{array}$ & $\begin{array}{l}\text { Negative } \\
\text { Positive } \\
\text { High avidity }\end{array}$ & $\begin{array}{c}\text { Asymptomatic: } \\
\text { absence of IgM and } \\
\text { high IgG avidity index } \\
\text { excluded recent } \\
\text { Toxoplasma spp. } \\
\text { infection }\end{array}$ \\
\hline 9 & No & Asymptomatic & $\begin{array}{l}\text { Well-done } \\
\text { heart }\end{array}$ & 2019 Jan 16 & 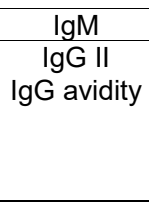 & $\begin{array}{c}\text { Negative } \\
\text { Positive } \\
\text { High avidity }\end{array}$ & $\begin{array}{c}\text { Asymptomatic: } \\
\text { absence of IgM and } \\
\text { high IgG avidity index } \\
\text { excluded recent } \\
\text { Toxoplasma spp. } \\
\text { infection }\end{array}$ \\
\hline 10 & No & Asymptomatic & None & $\begin{array}{c}\text { Did not } \\
\text { participate }\end{array}$ & NA & NA & NA \\
\hline
\end{tabular}

remaining 4 hunters who did not show development of symptoms, 1 consumed the uncooked heart of a deer, 2 consumed deer meat that was cooked well done, and 1 did not consume any deer meat on site. All other potential exposures were determined to be unremarkable. The Illinois Department of Public Health received reports of no similar illnesses in this area during the study period.

When the stay in Illinois ended, the hunters divided the remaining harvested meat among themselves and brought it back to Quebec. It was impossible to identify pieces of the deer partially consumed at the outfitter and possibly contaminated by $T$. gondii. At the beginning of the investigation, we recommended that the hunters not consume the deer meat until we knew more about the diagnosis. All deer meat was kept in freezers when the hunters returned home.

\section{Food Inspection Services by MAPAQ}

We collected 12 samples of frozen deer meat from 1 hunter household: 7 specimens of $300 \mathrm{~g}$ each and 5 
specimens of $500 \mathrm{~g}$ each from the same freezer. Among the 12 deer meat specimens collected for analysis, no T. gondii parasites were detected. Parts of deer that were consumed at the outfitter were unrecognizable from other parts of deer not consumed on site.

\section{Discussion}

Outbreaks of acute toxoplasmosis infection are unusual in Quebec. In Illinois, no outbreaks were reported to the public health unit over a 20-year period. We identified a game meat-associated outbreak in Quebec involving travel to Illinois. Investigative findings identified consumption of fresh, undercooked deer meat as the most likely source of infection.

Sporadic cases associated with deer meat consumption have been reported (13). During 2017, acute toxoplasmosis developed in 8 of 10 hunters after they consumed fresh deer meat in Wisconsin, USA (15).

During the outbreak we report, symptoms were severe enough that 1 case-patient had to be hospitalized and 3 other companions consulted a physician. Primary acquired Toxoplasma spp. infection is predominantly asymptomatic in immunocompetent persons in North America (17). During the outbreak we report, 6 of 7 nonimmune hunters for whom we had the information showed development of symptoms after infection. The severity of infection might depend on the genotype of the strain. The severity of infection is usually low in North America, where genotype II strains predominate (18), in comparison to other parts of the world (19-21).

Another major outbreak of toxoplasmosis involving hundreds of persons was reported in 1995 in Victoria, British Columbia, Canada. The suspected source was an infected cougar that had defecated in the watershed; heavy rains had then washed a bolus of oocysts into the water reservoir. The outbreak included a high proportion of severe primary infections among immunocompetent persons (18). In the locations of that outbreak and the outbreak we report (British Columbia and Quebec), the genotype was not determined. We are not able to explain why so many cases were reported among the immunocompetent population.

In our investigation, we obtained serum samples from 3 of the 4 asymptomatic hunters. Toxoplasma IgG was detected in 2 serum samples. The absence of IgM and the high IgG avidity index suggest that both of those hunters were already immune to $T$. gondii by a past infection. One asymptomatic hunter did not show development of any disease and showed negative results for toxoplasmosis even after consuming fresh deer meat that was rare. We do not have immune information about the fourth patient.
Food specimens collected from 1 hunter were negative for T. gondii. Unfortunately, parts of the deer that were consumed at the outfitter were unrecognizable from parts of other deer harvested in Illinois during the same period of time, which might explain the negative results.

Little is known of the natural epidemiology of $T$. gondii infection in white-tailed deer. Given that deer are strict herbivores, it is believed that they become infected postnatally by ingesting oocysts from the environment (7). When ingested, the parasites form tissue cysts in the skeletal muscle and other tissues. When the infected deer die, tissues are scavenged by feline carnivore species, including bobcats and cougars (7). The life cycle then continues, and these cats shed more oocysts into the environment. Estimated Toxoplasma spp. prevalence among white-tailed deer varies across the United States from $15 \%$ to $74 \%$ (Ohio, Pennsylvania, and Minnesota) $(7,9,10,12)$.

The MAPAQ Website provides general recommendations to game meat hunters and their family about safe handling and preparation (22). Recommendations include not eating raw or undercooked game meat and cooking to an internal temperature of at least $160^{\circ} \mathrm{F}$. They also recommend washing hands with soap and water after handling raw meat and cleaning all materials that come in contact with raw meat thoroughly after use. In addition, cysts and oocysts of toxoplasmosis might be destroyed by freezing the meat $(23,24)$. Because the prevalence seems to be high in wild animals in which study prevalence was determined, freezing the meat seems to be efficient to destroy cysts and oocysts. Hunters should be aware of those recommendations. A person can be infected for life and disease can reactivate years after the initial infection.

Few studies have reported on the seroprevalence of Toxoplasma antibodies in humans in Canada. In the United States, a nationwide study conducted during 2009-2010 showed that the overall T. gondii antibody seroprevalence among persons $>6$ years of age was $13.2 \%$ (24). Others reports found that, although the presence of $T$. gondii is still relatively common, the prevalence in the United States decreased during 1988-1994 $(25,26)$. Giving the high prevalence of Toxoplasma spp. in white-tailed deer across some areas of the United States and the overall observed decrease in seroprevalence in humans, outbreaks like the one we reported might be more common in the future, and health professionals should be aware of this possibility.

In this investigation, we recommendations to all hunters and their families that they not consume the 
deer meat. This recommendation was given even if all hunters were immunocompetent. If hunters and their families decided to consume the deer meat despite our recommendations, they were advised to freeze it thoroughly, cook it, and avoid distribution of the meat to family members, pregnant women, or immunocompromised persons.

\section{Acknowledgments}

We thank Philippe Jutras, Jean Longtin, and public health unit nurses and physicians for interviewing all hunters; and Connie Austin and Isabelle Gagnon for their active contributions to this study.

\section{About the Author}

Dr. Gaulin is a physician and epidemiologist at the Protection Branch, Ministry of Health, Quebec City, Quebec, Canada. Her primary research interests are infectious diseases, enteric and nonenteric disease surveillance, and provincial outbreak investigations.

\section{References}

1. Simon A, Bigras Poulin M, Rousseau AN, Dubey JP, Ogden NH. Spatiotemporal dynamics of Toxoplasma gondii infection in Canadian lynx (Lynx canadensis) in western Québec, Canada. J Wildl Dis. 2013;49:39-48. https:/ / doi.org/ 10.7589/2012-02-048

2. Dubey JP, editor. Toxoplasmosis of animals and humans, 2nd ed. Boca Raton (FL): CRC Press; 2010.

3. American Academy of Pediatrics. Red book: 2012. Report of the committee on infectious diseases. Elk Grove Village (IL): The Academy [cited 2019 Nov 19]. https:/ / redbook. solutions.aap.org/DocumentLibrary/RB12_interior.pdf

4. Aramini JJ, Stephen C, Dubey JP, Engelstoft C, Schwantje H, Ribble CS. Potential contamination of drinking water with Toxoplasma gondii oocysts. Epidemiol Infect. 1999;122:305-15. https://doi.org/10.1017/S0950268899002113

5. Shuhaiber S, Koren G, Boskovic R, Einarson TR, Soldin OP, Einarson A. Seroprevalence of Toxoplasma gondii infection among veterinary staff in Ontario, Canada (2002): implications for teratogenic risk. BMC Infect Dis. 2003;3:8. https:/ / doi.org/10.1186/1471-2334-3-8

6. Dubey JP. Toxoplasmosis in sheep, goats, pigs and cattle. In: Dubey J, Beattle C, editors. Toxoplasmosis in animals and man. Boca Raton (FL): CRC Press; 1988. p. 61-114.

7. Dubey JP, Dennis PM, Verma SK, Choudhary S, Ferreira LR, Oliveira S, et al. Epidemiology of toxoplasmosis in white tailed deer (Odocoileus virginianus): occurrence, congenital transmission, correlates of infection, isolation, and genetic characterization of Toxoplasma gondii. Vet Parasitol. 2014;202:270-5. https:/ / doi.org/10.1016/j.vetpar.2014.01.006

8. Jones JL, Dargelas V, Roberts J, Press C, Remington JS, Montoya JG. Risk factors for Toxoplasma gondii infection in the United States. Clin Infect Dis. 2009;49:878-84. https://doi.org/10.1086/605433

9. Dubey JP, Brown J, Verma SK, Cerqueira-Cézar CK, Banfield J, Kwok OC, et al. Isolation of viable Toxoplasma gondii, molecular characterization, and seroprevalence in elk (Cervus canadensis) in Pennsylvania, USA. Vet Parasitol. 2017;243:1-5. https:// doi.org/10.1016/j.vetpar.2017.05.030
10. Dubey JP, Jenkins MC, Kwok OC, Zink RL, Michalski ML, Ulrich V, et al. Seroprevalence of Neospora caninum and Toxoplasma gondii antibodies in white-tailed deer (Odocoileus virginianus) from Iowa and Minnesota using four serologic tests. Vet Parasitol. 2009;161:330-4. https:/ / doi.org/ 10.1016/j.vetpar.2009.01.002

11. Dubey JP, Velmurugan GV, Ulrich V, Gill J, Carstensen M, Sundar N, et al. Transplacental toxoplasmosis in naturally-infected white-tailed deer: isolation and genetic characterisation of Toxoplasma gondii from foetuses of different gestational ages. Int J Parasitol. 2008;38:1057-63. https:/ / doi.org/10.1016/j.ijpara.2007.11.010

12. Ballash GA, Dubey JP, Kwok OC, Shoben AB, Robison TL, Kraft TJ, et al. Seroprevalence of Toxoplasma gondii in whitetailed deer (Odocoileus virginianus) and free-roaming cats (Felis catus) across a suburban to urban gradient in northeastern Ohio. EcoHealth. 2015;12:359-67. https://doi.org/10.1007/s10393-014-0975-2

13. Ross RD, Stec LA, Werner JC, Blumenkranz MS, Glazer L, Williams GA. Presumed acquired ocular toxoplasmosis in deer hunters. Retina. 2001;21:226-9. https:/ / doi.org/ 10.1097/00006982-200106000-00005

14. Sacks JJ, Delgado DG, Lobel HO, Parker RL. Toxoplasmosis infection associated with eating undercooked venison. Am J Epidemiol. 1983;118:832-8. https:/ / doi.org/10.1093/ oxfordjournals.aje.a113701

15. Schumacher A, Kazmierczak J, Moldenhauer E, Hanhly T, Montoya J, Press C, et al. Toxoplasmosis associated with venison consumption during a retreat-Wisconsin, September-October 2017. Presented at: 67th Annual Epidemic Intelligence Service (EIS) Conference; 2018 Apr 16-19, 2018; Atlanta, Georgia, USA.

16. Kasper DC, Sadeghi K, Prusa AR, Reischer GH, Kratochwill K, Förster-Waldl E, et al. Quantitative real-time polymerase chain reaction for the accurate detection of Toxoplasma gondii in amniotic fluid. Diagn Microbiol Infect Dis. 2009;63:10-5. https://doi.org/10.1016/j.diagmicrobio. 2008.09.009

17. Montoya JG, Parmley S, Liesenfeld O, Jaffe GJ, Remington JS. Use of the polymerase chain reaction for diagnosis of ocular toxoplasmosis. Ophthalmology. 1999;106:1554-63. https:/ / doi.org/10.1016/S0161-6420(99)90453-0

18. Howe DK, Sibley LD. Toxoplasma gondii comprises three clonal lineages: correlation of parasite genotype with human disease. J Infect Dis. 1995;172:1561-6. https:/ / doi.org/ 10.1093/infdis/172.6.1561

19. Carme B, Bissuel F, Ajzenberg D, Bouyne R, Aznar C, Demar M, et al. Severe acquired toxoplasmosis in immunocompetent adult patients in French Guiana. J Clin Microbiol. 2002;40:4037-44. https:/ / doi.org/10.1128/ JCM.40.11.4037-4044.2002

20. Demar M, Ajzenberg D, Maubon D, Djossou F, Panchoe D, Punwasi W, et al. Fatal outbreak of human toxoplasmosis along the Maroni River: epidemiological, clinical, and parasitological aspects. Clin Infect Dis. 2007;45:e88-95. https:// doi.org/10.1086/521246

21. Mullens A. "I think we have a problem in Victoria": MDs respond quickly to toxoplasmosis outbreak in BC. CMAJ. 1996;154:1721-4.

22. Ministère de l'Agriculture, des Pêcheries et de l'Alimentation du Québec [cited 2019 Jul 29]. https:/ / www.mapaq.gouv. qc.ca/fr/Publications/FIche_Gibier_public_web.pdf

23. Guo M, Buchanan RL, Dubey JP, Hill DE, Lambertini E, Ying Y, et al. Qualitative assessment for Toxoplasma gondii exposure risk associated with meat products in the United States. J Food Prot. 2015;78:2207-19. https:/ / doi.org/ 10.4315/0362-028X.JFP-15-270 
24. Jones JL, Kruszon-Moran D, Rivera HN, Price C, Wilkins PP. Toxoplasma gondii seroprevalence in the United States 2009-2010 and comparison with the past two decades. Am J Trop Med Hyg. 2014;90:1135-9. https://doi.org/10.4269/ ajtmh.14-0013

25. Opsteegh M, Kortbeek TM, Havelaar AH, van der Giessen JW. Intervention strategies to reduce human Toxoplasma gondii disease burden. Clin Infect Dis. 2015;60:101-7. https://doi.org/10.1093/cid/ciu721
26. Jones JL, Kruszon-Moran D, Sanders-Lewis K, Wilson M. Toxoplasma gondii infection in the United States, 1999-2004, decline from the prior decade. Am J Trop Med Hyg. 2007;77:405-10. https://doi.org/10.4269/ajtmh.2007.77.405

Address for correspondence, Colette Gaulin, Ministère de la Santé et des Services Sociaux du Quebec, 1075 Chemin Ste-Foy, QC, Quebec G1S 2M1, Canada; email: colette.gaulin@msss.gouv.qc.ca

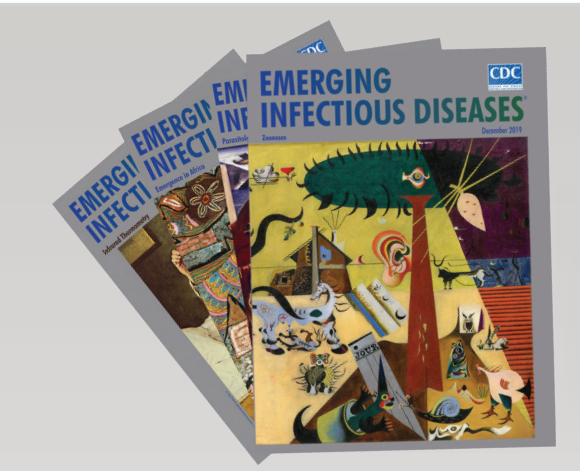

- Seroprevalence and Risk Factors Possibly Associated with Emerging Zoonotic Vaccinia Virus in a Farming Community, Colombia

- Patterns of Transmission and Sources of Infection in Outbreaks of Human Toxoplasmosis

- Global Epidemiology of Buruli Ulcer, 2010-2017, and Analysis of 2014 WHO Programmatic Targets

- Cost-effectiveness of Prophylactic Zika Virus Vaccine in the Americas

- Human Infection with Orf Virus and Description of Its Whole Genome, France, 2017

- High Prevalence of Macrolide-Resistant Bordetella pertussis and ptxP1 Genotype, Mainland China, 2014-2016

- Avian Influenza A Viruses among Occupationally Exposed Populations, China, 2014-2016

- Genomic Analysis of Fluoroquinolone- and Tetracycline-Resistant Campylobacter jejuni Sequence Type 6964 in Humans and Poultry, New Zealand, 2014-2016

- Streptococcus suis-Associated Meningitis, Bali, Indonesia, 2014-2017

- Epidemiologic, Entomologic, and Virologic Factors of the 2014-15 Ross River Virus Outbreak, Queensland, Australia

- Multicountry Analysis of Spectrum of Clinical Manifestations in Children $<5$ Years of Age Hospitalized with Diarrhea

- Sheep as Host Species for Zoonotic Babesia venatorum, United Kingdom

- Half-Life of African Swine Fever Virus in Shipped Feed

- Zika Virus IgM 25 Months after Symptom Onset, Miami-Dade County, Florida, USA

- Divergent Barmah Forest Virus from Papua New Guinea

- Animal Exposure and Human Plague, United States, 1970-2017

\section{December 2019}

- Sentinel Listeriosis Surveillance in Selected Hospitals, China, 2013-2017

- Economic Impact of Confiscation of Cattle Viscera Infected with Cystic Echinococcosis, Huancayo Province, Peru

- Predicting Dengue Outbreaks in Cambodia

- Cat-to-Human Transmission of Mycobacterium bovis, United Kingdom

- Evolution of Highly Pathogenic Avian Influenza A(H5N1) Virus in Poultry, Togo, 2018

-West Nile Virus in Wildlife and Nonequine Domestic Animals, South Africa, 2010-2018

- Highly Pathogenic Avian Influenza A(H5N8) Virus in Gray Seals, Baltic Sea

- Bagaza Virus in Himalayan Monal Pheasants, South Africa, 2016-2017

- Influenza A(H1N1)pdm09 Virus Infection in a Captive Giant Panda, Hong Kong

- Middle East Respiratory Syndrome Coronavirus Seropositivity in Camel Handlers and their Families, Pakistan

- Distantly Related Rotaviruses in Common Shrews, Germany, 2004-2014

- Molecular Confirmation of Rickettsia parkeri in Amblyomma ovale Ticks, Veracruz, Mexico

- Rhombencephalitis and Myeloradiculitis Caused by a European Subtype of Tick-Borne Encephalitis Virus

- Aspergillus felis in Patient with Chronic Granulomatous Disease

- Nodular Human Lagochilascariasis Lesion in Hunter, Brazil 